\section{PEPPERDINE}

UNIVERSITY
The Journal of Business, Entrepreneurship

\& the Law

\title{
Islamic Financing: A Successful Takeoff or a Crash Landing? Whether or Not Islamic Financing Should Be Used to Finance and Lease Aircraft
}

Jennifer Ann Urban

Follow this and additional works at: https://digitalcommons.pepperdine.edu/jbel

Part of the Air and Space Law Commons, Banking and Finance Law Commons, International Law Commons, and the Religion Law Commons

\section{Recommended Citation}

Jennifer Ann Urban, Islamic Financing: A Successful Takeoff or a Crash Landing? Whether or Not Islamic Financing Should Be Used to Finance and Lease Aircraft, 9 J. Bus. Entrepreneurship \& L. 329 (2016)

Available at: https://digitalcommons.pepperdine.edu/jbel/vol9/iss2/4

This Article is brought to you for free and open access by the Caruso School of Law at Pepperdine Digital Commons. It has been accepted for inclusion in The Journal of Business, Entrepreneurship \& the Law by an authorized editor of Pepperdine Digital Commons. For more information, please contact bailey.berry@pepperdine.edu. 


\title{
ISLAMIC FINANCING: A SUCCESSFUL TAKEOFF OR A CRASH LANDING? WHETHER OR NOT ISLAMIC FINANCING SHOULD BE USED TO FINANCE AND LEASE AIRCRAFT
}

\author{
JENNIFER URBAN ${ }^{1}$
}

I. Introduction 329

II. Background 331

III. The Middle East's Aviation History

A. Convention for the Unification of Certain Rules Relating to the Precautionary Attachment of Aircraft (The Rome Convention) .333

B. Convention on International Civil Aviation (The Chicago Convention)

C. Convention on the International Recognition of Rights in Aircraft (The Geneva Convention)

D. Convention on International Interests in Mobile Equipment and Protocol thereto on Matters Specific to Aircraft Equipment (The Cape Town Convention and Protocol)

IV. Islamic Financing Law

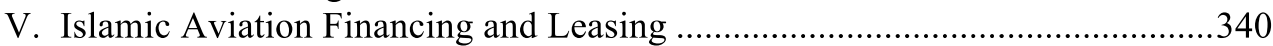

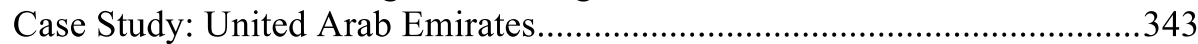

VI. Conclusion 349

\section{INTRODUCTION}

The worldwide aviation industry has grown significantly over the last decade and currently the Middle East is the fastest growing region for air travel. ${ }^{2}$ With a growing demand in air travel, there is a need for more ways to secure aviation

\footnotetext{
${ }^{1}$ Jennifer Ann Urban is a Mississippi Licensed Attorney and LL.M. Candidate in Air and Space Law at the University of Mississippi School of Law. She earned her J.D., M.B.A., and B.A. at the University of Mississippi. Ms. Urban would like to thank Professor Patrick Honnebier, international aviation financing and leasing attorney, for his helpful insights and support.

${ }^{2}$ Charles F. Yeterian, Islamic Financing Takes to the Air in the Aviation Industry, ISLAMIC FIN. NEWS: 2015 ANN. REP., Mar. 2015, at 12, http://islamicfinancenews.com/2015_supplement/guide/ IFNGuide.pdf.
} 
financing; one solution is Islamic financing. Islam is currently the fastest growing religion in the world ${ }^{3}$ and Islamic financing is one of the fastest growing areas of banking and hosts a benefit of financial stability; however, it is accompanied by legal instability. ${ }^{4}$ Due to the unique risk-sharing aspect of Islamic financing, it not only survived the global financial crisis, but also expanded as other financial institutions deteriorated. ${ }^{5}$ Al Hilal Bank, located in Abu Dhabi, was listed by Global Finance Magazine as the safest Islamic Bank in the United Arab Emirates (UAE). ${ }^{6}$ From 2006 to 2010, the growth of Islamic assets grew more in Middle Eastern countries than conventional banking assets did. ${ }^{7}$

Islamic financing can help diversify sources of funding, which makes it even more attractive to aviation finance lessors. ${ }^{8}$ In 2008, Davide Barzilai, Partner and Head of Islamic Finance - Asia Pacific at Norton Rose Fulbright LLP, stated "[w]e are seeing strong indications that Islamic financing is becoming more popular in aircraft finance because of difficulties in the conventional interest-based loan financing ... [f] ewer banks are lending, so Islamic finance can be used to wide choice and tap into the liquidity of the Middle East." Most recently, Mr. Barzilai's firm, Norton Rose Fulbright LLP, won multiple Islamic Finance Law News awards and advised Emirates Airlines on its nine-hundred eighty-three billion (United States dollars) sukuk, ${ }^{10}$ which was the first sukuk ever used for pre-funded aircraft financing. ${ }^{11}$ These recent deals show the continuing growth of Islamic financing and exemplify why other lessors and airlines should consider this type of aviation financing.

This paper begins with background information on the foundation of Islam. Then, it explains the applicable international treaties and their roles within Middle

\footnotetext{
${ }^{3}$ The Future of World Religions: Population Growth Projections, 2010-2050, PEW RES. CTR. (Apr. 2, 2015), http://www.pewforum.org/2015/04/02/religious-projections-2010-2050/.

${ }^{4}$ Mahmoud Mohieldin, Realizing the Potential of Islamic Finance, ECON. PREMISE, Mar. 2012, at 1, http://siteresources.worldbank.org/EXTPREMNET/Resources/EP77.pdf.

${ }^{5} \mathrm{Id}$.

${ }^{6}$ Gordon Platt, Middle East: Islamic Finance Flourishes, Global FIN. MAG. (MidDLE EAST 2014 SUPPLEMENT), Apr. 1, 2014, https://www.gfmag.com/magazine/april-2014/middle-east-islamicfinance-flourishes.

${ }^{7}$ Turkey had a 33\% compound annual growth rate in Islamic assets, while total assets only grew at a 19\% compound annual growth rate. Saudi Arabia had a 21\% compound annual growth rate in Islamic assets, while total assets only grew at a $13 \%$ compound annual growth rate. The United Arab Emirates had a $27 \%$ compound annual growth rate in Islamic assets, while total assets only grew at a $17 \%$ compound annual growth rate. Qatar had a $43 \%$ compound annual growth rate in Islamic assets, while total assets grew at a $32 \%$ compound annual growth rate. DEUTSCHE BANK, GLOBAL ISLAMIC BANKING REPORT 10 (2011); see also Mohieldin, supra note 4, at 4.

${ }^{8}$ Will Roberts, Sharia Deals Boost Aviation, 313 AIRfINANCE J., Sept. 1, 2008, at 30.

${ }^{9}$ Id.

10 "Sukuk are certificates of equal value representing undivided shares in ownership of tangible assets, usufruct and serves, or (in the ownership of) the assets of particular projects." Mohieldin, supra note 4 , at 7 .

${ }^{11}$ String of Islamic Finance News Award Wins for Norton Rose Fulbright, NORTON ROSE FULBRIGHT LLP (Apr. 9, 2015), http://www.nortonrosefulbright.com/news/127623/string-of-islamicfinance-news-award-wins-for-norton-rose-fulbright.
} 
Eastern nations. Next, Islamic finance law is addressed, followed by Islamic aviation financing and leasing in general. Finally, this paper concludes with a case study of how these principles come into practice in the UAE.

\section{BACKGROUND}

When comparative law issues are addressed, they are usually separated into two different legal systems: common law and civil law, while the third system is not as well known. Sharia law is the third main legal system that exists and it is used in over fifty-five Muslim countries and many other non-Muslim nations. ${ }^{12}$ Sharia law differs greatly from the other two forms and has many complexities based on religious tradition that has not fully been written down.

The Sharia is the religious law of Islam (also known as Islamic law). Sharia means the "way to water" and followers see it as the path that must be followed in order to reach heaven in the afterlife. ${ }^{13}$ It is based on the combination of the sunna and the hadith and the Qu'ran. ${ }^{14}$

Abu al-Qasim Muhammad ibn Abd Allah ibn Abd al-Muttalib ibn Hashim, known as Muhammad, is viewed as the greatest Islamic prophet. ${ }^{15}$ The sunna is a combination of religious, legal, and social responsibilities based on the prophet Muhammad's teachings that Muslims must follow. ${ }^{16}$ The hadith is a compilation of Muhammad's traditions and sayings based on his actual life. ${ }^{17}$ The sunna and the hadith are very difficult to separate, but the main difference is that the sunna is the entire collection of Islamic obligations attained from the hadith. ${ }^{18}$ While the Qur'an is a central religious authority for followers of the Islamic religion (it is known to be the word of God), the text itself has very little legal regulations; therefore, the potential for ambiguities and lack of consistency creates risk in its legal application. ${ }^{19}$

As J. N. D. Anderson states: "It is evident that Muhammad himself made no attempt to work out any comprehensive legal system, a task for which he seems to have been singularly ill-suited; instead, he contended himself with what went little beyond 'ad hoc' amendments to the existing customary law." 20 This does not mean that, within the Islamic religion laws do not exist; it is simply relevant to note the

\footnotetext{
${ }^{12}$ ANN Black ET AL, MOdern PERSPECTIVES ON ISLAMiC LAW 1 (2013).

${ }^{13}$ Hunt JANIN \& ANDRE KAHLMEYER, ISLAMIC LAW: THE SHARIA FROM MUHAMMAD's Time to THE PRESENT 1 (2007).

${ }^{14} \mathrm{Id}$. at 2.

${ }^{15} \mathrm{Id}$. at $10-11$.

${ }^{16} I d$. at 2 .

${ }^{17} \mathrm{Id}$.

${ }^{18}$ Id. at $2-3$.

${ }^{19}$ JANIN \& KAHLMEYER, supra note 13, at 2; S.D. Goitein, The Birth-Hour of Muslim Law?: An Essay in Exegesis, in 27 THE FORMATION OF THE ClASSICAL ISLAMIC WORLD, THE FORMATION OF IsLAMIC LAW 69, 70 (Wael B. Hallaq ed., 2004).

${ }^{20}$ J. N. D. Anderson, Recent Developments in Sharia Law, VOL. XL MuSLIM WorLd 245 (1950), quoted in Goitein, supra note 19.
} 
origin of the basis for the Sharia. There is a historic Arab and Israelite conception that proclaims, "[L]aw is a truth, which exists forever and which has only to be discovered by a wise man." ${ }^{21}$ This wise man who acted as the judge was called alhakem. $^{22}$ Muhammad acted as an al-hakem and primarily created the basis for Islamic law, formulating these regulations from the messages laid forth in the Qur'an. ${ }^{23}$

The Sharia is a very complex set of laws that are difficult for non-Muslims to follow because there is no complete written collection of all of the laws it encompasses. ${ }^{24}$ While describing current Islamic law, modern scholar Knut S. Vikor stated, "The Sharia is best understood as a shared opinion of the [Islamic] community, based on a literature that is extensive, but not necessarily coherent or authorized by any single body. 25

The Middle Eastern region is primarily governed by Sharia law, which can complicate business transactions for people who do not fully understand its fundamentals. In order to adequately complete business transactions within Middle Eastern countries, it is important to understand Islamic law, especially in regards to its distinct financial regulations. While Muslim countries are present all over the world, my primary focus group will be those in the Middle East region. The Middle East is primarily composed of seventeen countries: Afghanistan, Bahrain, Egypt, Islamic Republic of Iran, Iraq, Israel, Jordan, Kuwait, Lebanon, Oman, Pakistan, Qatar, Kingdom of Saudi Arabia, the Syrian Arab Republic, Turkey, the United Arab of Emirates, and Yemen. Israel is the only country in this region where Islam is not the primary religion. ${ }^{26}$

\section{The MidDle EAST'S AVIATION History}

While the Middle East has waivered in its past participation in international aviation law treaties, the region's involvement has increased over the past few decades. These treaties are critical in understanding how different types of aviation financing will be affected and how states have agreed to handle these different transactional issues, even if they end up dealing with them differently in actual practice.

\footnotetext{
${ }^{21}$ Goitein, supra note 19 , at 71.

${ }^{22} I d$.

${ }^{23} I d$. at 75 .

${ }^{24}$ JANIN \& KAHLMEYER, supra note 13, at 3.

${ }^{25} I d$. at 2-3.

${ }^{26}$ The World Factbook, CENT. INTELligenCE AGENCY, https:/www.cia.gov/library/publications/ the-world-factbook/wfbExt/region_mde.html (last visited Apr. 11, 2015).
} 


\section{A. Convention for the Unification of Certain Rules Relating to the Precautionary Attachment of Aircraft (The Rome Convention)}

The Rome Convention of 1933 was adopted by thirty-one states, mainly European countries. ${ }^{27}$ Egypt and Lebanon were the only two Middle Eastern countries that ratified ${ }^{28}$ the Rome Convention. ${ }^{29}$ As aircraft finance attorney B. Patrick Honnebier states, "[t]he intent of the Rome Convention is to immunize air transport from precautionary attachment." ${ }^{, 30}$ Article 3(1)(a) of the Rome Convention proclaims that there cannot be any arrests of state serviced aircraft ${ }^{31}$ and Article 3(1)(b) declares that there is only limited arrests available for commercial aircraft that are regularly scheduled. ${ }^{32}$ The exception to the limited arrest involves debts that arose for the trip that the aircraft is about to make or is currently making. ${ }^{33}$ Noncommercially operated aircraft do not fall under the precautionary arrest limitations; however, there is a way to get around a precautionary attachment. In order to get around the attachment, Article 4 requires that the debtor deposit a surety in the amount that it would take to cover the debt and costs, or an amount that is equivalent to the value of the aircraft if it is less than the debt and costs to the creditor. ${ }^{34}$ The current problem with this treaty is that it is outdated and instead of being helpful it is frustrating the repossession process because private financing has become dominate, as opposed to the past where it was seldom done. ${ }^{35}$ Unless a Contracting State has declared otherwise (which no state has done yet), the Cape Town Convention supersedes the Rome Convention. ${ }^{36}$ Therefore, it is not critical that only two of the

${ }^{27}$ B. Patrick Honnebier, Collecting EUROCONTROL Air Navigation Charges By Precautionary Arresting the Aviation Fuel of Aircraft in the European Netherlands, 12 J. LUCHTRECHT 33, 36 (2013).

${ }^{28}$ Ratification is the most common way for a state to become a party to an international treaty. It is a two-step process where the State first signs the treaty, and then, after it has decided to formally adhere to it, the State ratifies the treaty. Acceptance and approval of a treaty are generally synonymous to ratification. After the ratification occurs, the State is officially a state party, and all of the obligations within the treaty are binding on the State, unless the ratification had specific reservations. Key Terms on Treaty Adherence, Geneva ACAD. InT'L HumanitARIAN L. \& HuM. RTS., http://www.genevaacademy.ch/RULAC/pdf/Key-definitions-relating-to-treaty-adherence.pdf (last visited on Apr. 28, 2015).

${ }^{29}$ Honnebier, supra note 27.

${ }^{30} \mathrm{Id}$. at $36-37$.

${ }^{31} \mathrm{Id}$. at 37.

${ }^{32} I d$.

${ }^{33} I d$.

${ }^{34} \mathrm{Id}$.

${ }^{35}$ B. Patrick Honnebier, Professor of Int'l Aviation Fin. \& Leasing Laws, Univ. of Miss., Lecture Slides: Convention on Precautionary Arrest of Aircraft (Rome, 1933) 7-8 (2015) (on file with author).

${ }^{36}$ Article XXIV - Relationship with the Convention for the Unification of Certain Rules Relating to the Precautionary Attachment of Aircraft:

1. The Convention shall, for a Contracting State that is a Party to the Convention for the Unification of Certain Rules Relating to the Precautionary Attachment of Aircraft, signed at Rome on 29 May 1933, supersede that Convention as it relates to aircraft, as defined in this Protocol.

2. A Contracting State Party to the above Convention may declare, at the time of ratification, acceptance, approval of, or accession to this Protocol that it will not apply this Article. 
Middle Eastern countries ratified the Rome Convention.

\section{B. Convention on International Civil Aviation (The Chicago Convention)}

The focus of the Chicago Convention of 1944 was to develop uniform rules for international civil aviation that promote safety, economics, and the creation of international air transport services. ${ }^{37}$ The important articles of this Convention for aviation financing and leasing are Articles $17,{ }^{38} 18,{ }^{39}$ and $19,{ }^{40}$ which deal with the nationality of an aircraft and its registration. ${ }^{41}$ One hundred ninety-one countries either ratified or sent in notice of adherence ${ }^{42}$ to the Chicago Convention. All of the Middle Eastern countries are parties to this Convention and, therefore, are all bound by it. Ten Middle Eastern countries sent in notice of their adherence to this Convention and seven countries ratified it. ${ }^{43}$ While the Chicago Convention did have great participation, even from Middle Eastern nations, it failed to deal with the transfer of ownership of aircraft, along with other issues that have arisen over the last seventy years that remain problematic today. ${ }^{44}$

\section{Convention on the International Recognition of Rights in Aircraft (The Geneva Convention)}

Per its preamble, the goal of the Geneva Convention of 1948 was to create internationally recognized rights in aircraft. ${ }^{45}$ Contracting States had to recognize rights under the Geneva Convention before they could recognize any other rights,

Protocol to the Convention on International Interests in Mobile Equipment on Matters Specific to Aircraft Equipment art. XXIV, Nov. 16, 2001, 2307 U.N.T.S. 285, http://www.unidroit.org/english/conventions/ mobile-equipment/aircraftprotocol.pdf [hereinafter Cape Town Protocol].

37 Convention on International Civil Aviation pmbl., Dec. 7, 1944, 61 Stat. 1180 http://www.icao.int/publications/Documents/7300_cons.pdf [hereinafter Chicago Convention].

${ }^{38}$ Article 17-Nationality of Aircraft: "Aircraft have the nationality of the State in which they are registered." Chicago Convention, supra note 37, at art. 17.

${ }^{39}$ Article 18-Dual Registration: "An aircraft cannot be validly registered in more than one State, but its registration may be changed from one State to another." Chicago Convention, supra note 37, at art 18.

${ }^{40}$ Article 19-National Laws Governing Registration: "The registration or transfer of registration of aircraft in any contracting State shall be made in accordance with its laws and regulations." Chicago Convention, supra note 37, at art. 19.

${ }^{41}$ B. Patrick Honnebier, Professor of Int'l Aviation Fin. \& Leasing Laws, Univ. of Miss., Lecture Slides: Overview [of] Various Aviation Finance Treaties and Their Scope and Intent 1 (2015) [hereinafter Overview of Various Aviation Finance Treaties] (on file with author).

${ }^{42}$ Adherence to a Treaty is defined as "the process of becoming a state party to a treaty, for example through signature and ratification, or through accession." Key Terms on Treaty Adherence, supra note 28.

${ }^{43}$ See infra app. A; see also Convention on International Civil Aviation Signed at Chicago on 7 December 1944, INT'L CIV. AVIATION ORG., http://www.icao.int/secretariat/legal/List\%20of\%20 Parties/Chicago_EN.pdf (last visited Apr. 11, 2015).

${ }^{44}$ Overview of Various Aviation Finance Treaties, supra note 41.

${ }^{45}$ Convention on the International Recognition of Rights in Aircraft pmbl., June 19, 1948, 4 U.S.T. 1833, https://www.loc.gov/law/help/us-treaties/bevans/m-ust000004-0758.pdf [hereinafter Geneva Convention]. 
therefore creating uniform rules regarding priority in interests. ${ }^{46}$ This Convention is not well liked by the majority of the aviation scholarly community, as it does not sufficiently address asset-based aviation financing and leasing deals or nonconsensual rights in aircraft. ${ }^{47}$ Additionally, the Convention is outdated in part because at the time there was no way to have a "uniform proprietary regime"therefore no proprietary rights can be acquired from it. ${ }^{48}$

The Geneva Convention had eighty-nine states deposit an instrument of ratification, adherence, or succession. ${ }^{49}$ Eight Middle Eastern countries deposited an instrument to this treaty. ${ }^{50}$ Iran was the only Middle Eastern country that signed the Geneva Convention, but did not deposit an instrument of ratification, adherence, or succession. ${ }^{51}$

\section{Convention on International Interests in Mobile Equipment and Protocol thereto on Matters Specific to Aircraft Equipment (The Cape Town Convention and Protocol)}

Due to the high level of ratification of the Cape Town Convention and Protocol by Middle Eastern countries and the relevant modern rules it established, this Convention is regarded as the most significant treaty pertaining specifically to international aviation financing and leasing. The main purpose of the Cape Town Convention was to aid in the financing of mobile equipment while providing property rights protection and legal certainty to financers, lessors, and operators through the creation of an International Registry system. ${ }^{52}$ There are sixty-five contracting states to the Cape Town Convention and there are fifty-seven contracting states to the Aircraft Equipment Protocol. ${ }^{53}$ Eleven Middle Eastern countries have ratified the Cape Town Convention and ten have ratified the Cape Town Protocol. ${ }^{54}$ The Syrian Arab Republic differed from many of the other Middle Eastern countries in that it ratified the Cape Town Convention, but not the Protocol. When giving the

\footnotetext{
${ }^{46}$ Geneva Convention, supra note 45 , at art. 1.

${ }^{47}$ B. Patrick Honnebier, Professor of Int'l Aviation Fin. \& Leasing Laws, Univ. of Miss., Lecture Slides: Convention on the International Recognition of Rights in Aircraft (Geneva Convention, 1948) 78 (2015) (on file with author).

${ }^{48} I d$. at 6.

${ }^{49}$ Convention on the International Recognition of Rights in Aircraft Signed at Geneva on 19 June 1948, INT'L CIV. AVIATION ORG., http://www.icao.int/Secretariat/Legal/List\%20of\%20Parties/Geneva_ EN.pdf (last visited Apr. 12, 2015).

${ }_{51}^{50}$ See id.; see also app. B.

${ }^{51}$ Convention on the International Recognition of Rights in Aircraft Signed at Geneva on 19 June 1948, supra note 49.

${ }_{52}$ Convention on International Interests in Mobile Equipment (Cape Town 2001)—Status, UNIDROIT, http://www.unidroit.org/status-2001 capetown (last visited Apr. 11, 2015).

${ }_{53}$ Id.; Protocol on the Convention on International Interests in Mobile Equipment on Matters Specific to Aircraft Equipment-Status, UNIDROIT, http://www.unidroit.org/status-2001capetownaircraft (last visited Apr. 11, 2015) [hereinafter Status of Aircraft Equipment Protocol].

${ }^{54}$ See Status of Aircraft Equipment Protocol, supra note 53; see also app. C.
} 
Presentation as to why states should approve this Convention, the Kingdom of Saudi Arabia argued that it went beyond the limitations of the Geneva Convention and the Rome Convention. ${ }^{55}$ Furthermore, they claimed that the Cape Town Convention was beneficial to both creditors and debtors, because through international guarantees debtors would be able to access financial credit and aircraft creditors had a way to protect their loans if the debtors defaulted. ${ }^{56}$

As long as the state has acceded to Article VIII of the Protocol, ${ }^{57}$ the parties to an aircraft lease or financing agreement can agree upon the law that will regulate their contractual obligations and rights. ${ }^{58}$ This choice of law does not have an effect on third parties. ${ }^{59}$ Therefore, if the contracting parties choose for the agreement to be governed by the United States law, ${ }^{60}$ and the aircraft was registered in the UAE, the UAE would have to respect the governing nation's laws when analyzing issues regarding contractual rights and obligations that may arise. The Cape Town Convention is superior to any national laws of the countries that have ratified it and have made declarations, according to Article $\mathrm{XXX}(1),{ }^{61}$ stating they will apply Article VIII of the Protocol. According to the Aviation Working Group (AWG), "[b]y effective implementation, AWG means that qualifying declarations under the OECD's [Organization for Economic Co-operation and Development] Aircraft Sector Understanding have been made and that the Cape Town Convention has the force of law in Contracting States, and, to the extent of any conflict, prevails over other laws in such States." ${ }^{2}$ Six of the ten Middle Eastern countries that have ratified

\footnotetext{
${ }^{55}$ Kingdom of Saudi Arabia, Agenda Item 47: Work Programme of the Organization in the Legal Field, Convention on International Interests in Mobile Equipment and its Protocol Related to Matters Specific to Aircraft Equipment (Int'l Civ. Aviation Org., Working Paper No. 234, 2007), http://www. icao.int/Meetings/AMC/MA/Assembly\%2036th\%20Session/wp234_en.pdf.

${ }_{57}^{56} I d$.

(1) This Article applies only where a Contracting State has made a declaration pursuant to Article $\mathrm{XXX}(1)$; (2) The parties to an agreement, or a contract of sale, or a related guarantee contract or subordination agreement may agree on the law which is to govern their contractual rights and obligations, wholly or in part; [and] (3) Unless otherwise agreed, the reference in the preceding paragraph to the law chosen by the parties is to the domestic rules of law of the designated State, or, where that State comprises several territorial units, to the domestic law of the designated territorial unit.

Cape Town Protocol, supra note 36, at art. VIII.

${ }^{58}$ Emma Giddings, 10 Things to Know About Leasing and Financing Aircraft in the UAE, LEXICOLOGY (Nov. 13, 2013), http://www.lexology.com/library/detail.aspx?g=e886c5d9-a30c-4f55832b-c6d6f99f59c6; Roy Goode, Official Commentary-The Cape Town Convention on International Interests in Mobile Equipment: a Driving Force for International Asset-Based Financing, 7 UNIF. L. REV. 3, 3-15 (2002), http://www.unidroit.org/english/publications/review/articles/2002-1-goode-e.pdf.

${ }^{59}$ Cape Town Protocol, supra note 36.

${ }^{60}$ Convention on International Interests in Mobile Equipment, Nov. 16, 2001, 2307 U.N.T.S. 285, http://www.unidroit.org/english/conventions/mobile-equipment/mobile-equipment.pdf [hereinafter Cape Town Convention]; Cape Town Protocol, supra note 36.

61 "A Contracting State may, at the time of ratification, acceptance, approval of, or accession to this Protocol, declare that it will apply any one or more of Article VIII, XII and XIII of this Protocol." Cape Town Protocol, supra note 36, at art. XXX, § 1.

${ }^{62}$ Ratification and Implementation of the Cape Town Convention, AVIATION WORKING Group,
} 
the Protocol have made declarations regarding Protocol Article VIII. ${ }^{63}$

While the AWG does list the countries that have made declarations regarding Protocol Article VIII, it specifically notes that "[t]his summary is based on legal elements rather than actual practice, i.e.[,] the summary indicates legal rule and not whether the relevant institutions (courts and civil authorities) in a country have enforced or will enforce the rule." principles of Islamic aviation financing law may not agree with the laws of the country chosen, by the contracting parties, to govern the agreement. ${ }^{65}$ For example, the UAE has ratified the Cape Town Convention and has made a declaration concerning the application of Article VIII of the Protocol. ${ }^{66}$ In the past, UAE courts have usually decided that UAE law, based on Islamic law, should apply to a contract despite contracting parties having chosen another country's laws to apply. ${ }^{67}$ According to attorney Emma Giddings, "[i]t is unclear whether the accession by the UAE to the Cape Town Convention would mean[,] in practice[,] that a UAE court would respect the choice of a law other than UAE law as the governing law of a lease." ${ }^{\prime 68}$ This potential problem is an important factor for contracting parties to take into consideration when deciding which country's law governs their agreement and what structure should apply. ${ }^{69}$

\section{ISLAMIC FINANCING LAW}

While the phrases "Islamic financing" and "Islamic aircraft finance law" are not recognized within scholarly terminology as existing as actual legal methods, they have developed through the interpretation and combination of Islamic law and manmade law. The fact that the law is based on the interpretation of religion does make this type of finance riskier, per se, because many scholars disagree on the proper interpretation and how that interpretation should be combined with the man-made laws developed for modernization.

Uncertainty as to how potential conflicts would be resolved under Sharia law is one of the biggest concerns of financing within the Middle East. According to Bloomberg:

The industry is also challenged by high costs due to the complexity of the instruments and the fees paid to scholars to certify [S]haria compliance. And many products,

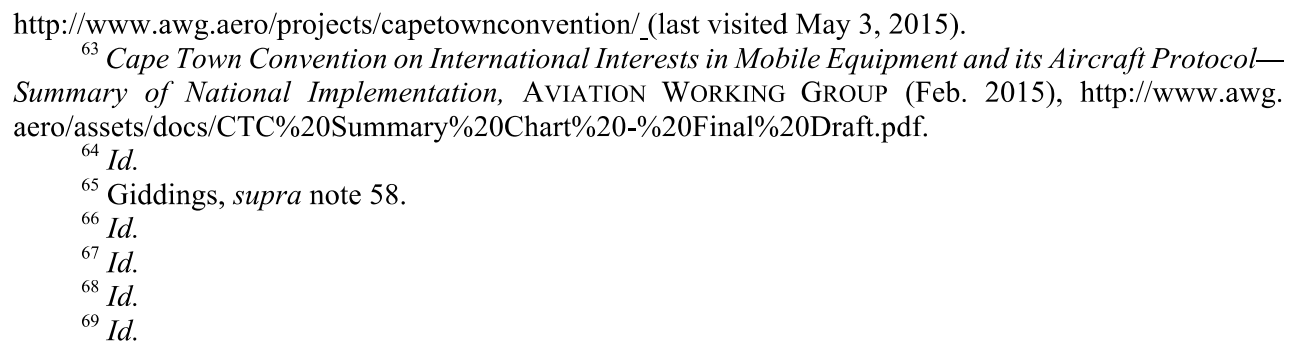

${ }^{67} \mathrm{Id}$.

${ }^{68} I d$.

${ }^{69}$ Id. 
such as hedging instruments and short-term government securities, are in short supply. Progress in establishing common standards for sharia-compliance has been slow, creating the risk that instruments could be declared unacceptable, as several sukuk have been after issuance. ${ }^{70}$

Although there are these risks, the law is not without structure and there are many benefits, such as the shared risk between all parties of the transaction and the strength through the recent financial crisis, that make Islamic financing a contender in the financial world.

While many other countries have been battling the financial crisis that weakened economies globally, Middle Eastern nations have experienced continued economic growth. Supporters of Islamic financing laws argue that Sharia law forces the banking institutions to not only look out for their own best interests, but their clients' best interests as well. This is partially because according to the Qur'an, only Allah can own property $;^{71}$ therefore, the transaction must be for the betterment of everyone involved. The banks and lenders do this by themselves owning any of the assets that the debtors have borrowed money for, until the full amount has been repaid; therefore, both the creditor and the debtor assume risk and loans that are too great for the debtor to repay are avoided. ${ }^{72}$ Middle Eastern financial markets have been highly sought after by Westerners. For example, reputable banks such as HSBC, Deutsche Bank, and Citigroup have all been working rigorously to gain traction in creating financial instruments that fit within Islamic law. ${ }^{73}$

One potential issue is that these new banks may not fully understand that, even with specific laws set in place within Middle Eastern countries, there is always a possibility of unpredictability as to how conflicts may be resolved within the different countries' court systems when Sharia law fundamentals must be considered.

An aspect that significantly differentiates Islamic finance law from many other finance laws around the world is the prohibition of riba, which means interest or usury. $^{74}$ According to the Qur'an, interest may not be added to loans or deposits, which some would argue complicates the financial structure of countries that abide by Sharia law. ${ }^{75}$ Scholars claim that there are two main reasons behind this prohibition. First, the Qur'an states, "Believers, do not live on usury, doubling your

70 Simon Harvey, Islamic Finance, BLOOMBERG QUICKTAKE, http://www.bloombergview. com/quicktake/islamic-finance (last updated June 10, 2015, 12:12 PM).

${ }^{71}$ Qur'an 7:128 states: "[T] he earth is Allah's, [t]o give as a heritage [t]o such of His servants as He pleaseth[,]" quoted in Angelo Luigi Rosa, Harmonizing Risk and Religion: The Utility of Shari'aCompliant Transaction Structuring in Commercial Aircraft Finance, 13 MINN. J. GLOBAL TRADE 35, 37 (2004).

${ }^{72}$ BLACK ET AL., supra note 12, at 177.

${ }^{73} \mathrm{Id}$.

${ }^{74}$ JANIN \& KAHLMEYER, supra note 13, at 170.

${ }^{75} \mathrm{Id}$. 
wealth many times over. Have fear of God, that you may prosper."76 During the lifetime of Muhammad (c.570-632), Mecca had an advanced trading system, where a debtor had a specified time frame in which he had to pay for his transactions. ${ }^{77}$ If the debtor failed to pay back the debt, he got more time to pay it back; however, with the extension of time the amount he owed was completely doubled, which Muhammad declared was inequitable and the tradition of prohibiting riba began. ${ }^{78}$ Second, Muhammad's beliefs went against the addition of interest to financial transactions done by the Hebrews and backed up his belief with the passage in the Qur'an that stated, "because they practice usury - although they were forbidden it and cheat others of their possessions. Woeful punishment have We prepared for those that disbelieve." ${ }^{, 79}$ Muhammad did not want practitioners of Islam to benefit from the financial suffering of others and instead wanted all parties to share in the losses or profits that might occur.

The view as to which business transactions fall under the prohibition of riba is inconsistent and many scholars argue it is open to interpretation as long as the general principles are applied.

Even the prohibitions of gambling and of taking interest, though directly concerned with certain types of contracts, are not meant to lay down legal rules regulating the form and effects of these contracts, but to establish moral norms under which they are allowed or prohibited. The idea that such contracts, if they are concluded notwithstanding the prohibition, are invalid and do not create obligations, does not yet appear in the Qur'an. ${ }^{80}$

Gharar means uncertainty and refers to the Islamic law that any gains or losses must be known to the parties prior to the transaction ${ }^{81}$ According to Ibn Ham, "[g]harar in sale occurs when the purchaser does not know what he has bought and the seller does not know what he has sold." ${ }^{2}$ Transactions under Sharia law must be transparent and fair, while details including specifications of counter-values and future delivery, no matter how minute, must be provided to everyone involved. ${ }^{83}$ This solidifies that neither party has taken advantage of anyone else by completing the deal. Generally, if the transaction involves a significant substantial risk (gharar fahish), it is prohibited by Sharia law. However, if the exchange only garners a

\footnotetext{
${ }^{76}$ Qur'an, 3:130; JANIN \& KAHLMEYER, supra note 13, at 170.

${ }^{77}$ JANIN \& KAHLMEYER, supra note 13, at 10, 170.

${ }^{78} I d$. at 170.

${ }^{79}$ Qur'an, 4:161; JANIN \& KAHLMEYER, supra note 13, at 170-71.

${ }^{80}$ Joseph Schacht, Pre-Islamic Background and Early Development of Jurisprudence, in 27 THE FORMATION OF THE ClASSICAL ISLAMIC WORLD, THE FORMATION OF ISLAMIC LAW 29, 32 (Wael B. Hallaq ed., 2004).

${ }^{81}$ JANIN \& KAHLMEYER, supra note 13, at 187. $8,1960))$.

${ }^{82}$ BLACK ET AL., supra note 12, at 178 (quoting IBN HAZM, AL-MuHALLA 343 (Dar al-'Uruba, vol.

${ }^{83}$ BLACK ET AL., supra note 12, at 178.
} 
minimal degree of risk (gharar yasir), it may be allowed. ${ }^{84}$ Risk sharing is a key feature of Islamic financing law, which depending on the transaction can be one reason to conduct business under Sharia law rather than traditional finance law.

Islamic banks and lending institutions differ from the more Westernized banks around the world. Islamic banks work with the actual goods and titles to the assets their clients are purchasing. Islamic banks "use money only as a medium of exchange for purchasing the goods for the purpose of leasing or selling onward, thereby earning income or profit." ${ }^{, 55}$ An example of this would be for the bank to buy an aircraft itself, then re-sell it to an airline for a profit, and the buyer would pay for the aircraft in smaller amounts. There would be strict guidelines in this example, such as the fact that there could not be late payment penalties because that would constitute riba. Therefore, if the airline is not able to pay for the aircraft then strict default would occur. ${ }^{86}$ More conventional banks deal heavily in money, such as in lending when the banks give the client money to buy the asset and then the client must pay back the amount lent plus interest.

The bank in this case would not keep the actual asset or ownership like the Islamic bank would. ${ }^{87}$ Using the same example, if the transaction were done with an American bank, it is likely the bank would lend the money needed to purchase the aircraft to the airline and the airline would need to pay back the money in installments with additional interests added.

Another type of Islamic financing tool is ijara, known as leasing. This is not the typical lease and there are important differences to keep in mind. For example, one main difference is, "the requirement of the lessor to assume the risk relating to ownership of the leased asset at all times, and that any sale to the lessee at the end of the lease period must not be a condition of the leasing contract." ${ }^{\prime 88}$ The bank would make a profit from the amount charged on the cost of the leased asset, which is to be included in any cost within the repayments to the bank. ${ }^{89}$

\section{ISLAMIC AVIATION FINANCING AND LEASING}

A key part of stability and continued growth for air travel is access to an assortment of different financing options. ${ }^{90}$ The recent financial crisis was the cause of uncertainty in many traditional financial structures. ${ }^{91}$ Through the strength and rising presence of Islamic financing during the financial crisis, it has become another

\footnotetext{
${ }^{84}$ JANIN \& KAHLMEYER, supra note 13, at 171.

${ }^{85}$ BLACK ET AL., supra note 12 , at 185-86.

${ }^{86} \mathrm{Id}$. at $186-87$.

${ }^{87} \mathrm{Id}$. at 185 .

${ }^{88} I d$. at 187.

${ }^{89} \mathrm{Id}$.

${ }^{90}$ Yeterian, supra note 2.

${ }^{91}$ Id.
} 
alternative for aviation financing and leasing. ${ }^{92}$ The Middle Eastern region is booming with international travel. ${ }^{93}$ For example, Dubai International Airport recently earned the title of the world's busiest international airport. ${ }^{94}$ According to Islamic Finance News' 2015 Annual Report, "[t]his [air travel] expansion is particularly important from the perspective of Islamic financing as Boeing is forecasting around two-thirds of commercial aircraft deliveries to the Middle East region will be supported by debt sourced from locally-based banks with a natural inclination to promote Islamic lease and financing structures." 95 This increase in aviation financing within the Middle Eastern region is not predicted to slow anytime soon. As stated by Nouvus Aviation Capital's Senior Advisor, Charles F. Yeterian, "[w]ith the financing parameters and asset value characteristics of commercial aircraft so well suited to Sharia principles, the growth of Islamic financing in the aircraft sector appears cleared to take off." 96

The key characteristic of whether or not the aviation financial transaction will pass Sharia law's standards depends on how the lender is obtaining a profit and how this profit affects all of the parties involved. ${ }^{97}$ Since aircrafts are physical assets, there are three main structures that Islamic aviation finance transactions may form. ${ }^{98}$ First, the structure most similar to conventional financial transactions used by the United States is called Bay'mu'ajjal, meaning credit sale. ${ }^{99}$ This structure is essentially an agreement between the parties for the buyer to pay the price of the asset at a specified time in the future. ${ }^{100}$ The contract is likely to include a provision that states if the buyer defaults on a payment, the entire amount owed will be due immediately. ${ }^{101}$ The second structure known as murabahah, ${ }^{102}$ is where the lender actually buys aircraft or parts thereto and then the lender itself sells the aircraft or parts to the lessor after marking up its price. The lessor can then make smaller

${ }^{92} I d$.

${ }^{93} I d$.

${ }^{94} I d$.

${ }^{95} I d$. at 12 .

${ }^{96} \mathrm{Id}$. at 14.

${ }^{97}$ Rosa, supra note 71 , at 44 .

${ }^{98} \mathrm{Id}$.

${ }^{99} \mathrm{Id}$.

${ }^{100}{ }^{B a i}$ ' Mu'ajjal, CONCEPTS ISLAMIC ECON. \& Fin. (Apr. 16, 2006, 9:34 P.M.), https://cief. wordpress.com/2006/04/16/bai-muajjal/.

${ }^{101} I d$.

102 Murabahah is a sale of goods with an agreed upon profit mark up. There are two types of murabahah sales: an example of the first type is when an Islamic bank purchases goods and makes them available for sale without any prior promise from a customer to purchase them. An example of the second type is when an Islamic bank purchases the goods ordered by a customer from a third party and then sells these goods to the same customer. In the later case, the Islamic bank purchases the goods only after a customer has made a promise to purchase them from the bank.

Moheildin, supra note 4, at 6 . 
payments to the lender until the entire asset is paid off. ${ }^{103}$ The final structure is ijara, which has been discussed above. In an ijara aircraft financial transaction, the lessor would buy aircraft or parts thereto and then lease them to the client with the addition of a rental fee. ${ }^{104}$

The three Islamic aviation finance structures do not have to be done separately and instead the combination of them can sometimes provide the best transaction. The most common combination of the structures is called an ijara wa-iqtina, which is when the murabahah structure and ijara structure are blended. ${ }^{105}$ An ijara wa-iqtina is essentially two separate transactions with the involvement of the same parties. ${ }^{106}$ The first transaction would be the ijara where the lessor owns the aircraft and leases it to the lessee. ${ }^{107}$ The second transaction would have to occur at the end of the ijara and, after all of the leasing payments have been made, the lessee would then have the option to buy the aircraft. ${ }^{108}$ There are three main conditions of an ijara waiqtina. ${ }^{109}$ First, the leasing agreement for the aircraft and the transfer of ownership of the aircraft have to be done in two completely separate documents. ${ }^{110}$ Second, as mentioned above, in order for the two transactions to be completely independent there cannot be any pre-condition added to the ijara that there will be a transfer of ownership. ${ }^{111}$ Last, the murabahah part, or the promise to transfer ownership of the aircraft, can only be done by the lessor and it can only bind the lessor, not the lessee. ${ }^{112}$ One reason this structure is preferred is because:

Both traditional lease financing and the ijara wa-iqtina structure have the ability to produce a fixed debt obligation that can be collateralized. Since the price of the asset is fixed under Islamic sale/lease arrangements, future benefit streams may be quantified for the purposes of hedging risk, and . . . the lease terms can reflect prevailing interest rates for the purposes of pricing the lease. 113

The ijara wa-iqtina gives the lessor the ability to make a profit for its work and risk taking on this transaction. The terms of the profit from the leasing transaction need to be included within the leasing agreement and the terms of the profit from the transfer of ownership need to be contained in the sale agreement. ${ }^{114}$

${ }^{103}$ Rosa, supra note 71 , at 44 .

${ }^{104} \mathrm{Id}$.

${ }^{105} \mathrm{Id}$. at 45.

106 Islamic Finance, IJARA COMMUNITY DEV. CORP., https://ijaracdc.com/sharia-compliance/ islamic-finance/ (last visited Apr. 12, 2015).

${ }^{107} \mathrm{Id}$.

${ }^{108} I d$.

${ }^{109} \mathrm{Id}$.

${ }^{110} \mathrm{Id}$.

${ }^{111} I d$.

${ }^{112} \mathrm{Id}$.

${ }^{113}$ Rosa, supra note 71 , at 45.

${ }^{114}$ Id. 


\title{
Case Study: United Arab Emirates
}

The United Arab Emirates (UAE), especially its cities Dubai and Abu Dhabi, is currently one of the top five fastest growing economies in the world and is known for its two primary airlines Emirates and Etihad, making it an optimal place for aviation financing and leasing laws to come into play. ${ }^{115}$ This can become complex, because Article 7 of the UAE's constitution proclaims that Islam is the national religion and Islamic Sharia is the main source of legislation. ${ }^{116}$ Although the Sharia is the main source of legal guidance, it is not the only source. ${ }^{117}$ Usually, courts within the UAE will rule according to the Sharia if there is not specific legislation on the matter that is contrary to the Sharia, ${ }^{118}$ which creates uncertainty and unpredictability as to how future issues in the UAE will be decided by the courts. The uncertainty creates an aspect of risk as to what might happen if a legal issue arose within an aviation financing deal in the UAE, which is one reason some may not want to lease there.

While aviation financing and leasing within the UAE does carry the risk of uncertainty, the UAE should not be excluded for these types of transactions because there are also many benefits under the Sharia. According to the United States Library of Congress's Federal Research Division,

\begin{abstract}
Islamic banking has assumed a more prominent role in the UAE in recent years, and most conventional banks are opening or expanding Islamic banking departments; sharia-compliant consumer and investment products also are being introduced. Government agencies and majority state-owned companies are using Islamic bondssukuk-to finance development and acquisitions. ${ }^{119}$
\end{abstract}

Because many UAE nationals are Muslim, and due to the fact that many government departments are using sukuk, there is a good chance that the Sharia will govern the registration of aircraft in the UAE. Only aircraft owned by UAE nationals, UAE government departments, or companies that have their primary place of business in the UAE can be registered on the UAE register. ${ }^{120}$ Also, aircraft that have been leased to a UAE government department, also referred to as a Qualifying Person,

${ }^{115}$ Joshua Robinson, The 20 Fastest-Growing Economies This Year, BLOOMBERG Bus. (Feb. 25, 2015, 10:01 AM), http://www.bloomberg.com/news/articles/2015-02-25/the-20-fastest-growingeconomies-this-year.

${ }^{116}$ Constitution of the United Arab Emirates, World InTEll. Prop. Org., http://www.wipo.int/ wipolex/en/details.jsp?id=10673E (last visited Apr. 30, 2015).

${ }^{117}$ Diana Harmade, Defining Sharia's Role in the UAE's Legal Foundation, NAT'L (June 27, 2011), $\mathrm{http} / / \mathrm{www}$.thenational.ae/thenationalconversation/comment/defining-sharias-role-in-the-uaes-legalfoundation.

${ }^{118} I d$.

${ }^{119}$ Country Profile: United Arab Emirates (UAE), LiBr. CONGRESs-FED. RES. Div., 12 (July 2007), https://www.loc.gov/rr/frd/cs/profiles/UAE.pdf.

${ }^{120}$ Giddings, supra note 58. 
may be included on the UAE register. ${ }^{121}$

In order to register aircraft, the entity must apply for an authorization code from the UAE's General Civil Aviation Authority (GCAA). ${ }^{122}$ An authorization code is also needed for each entity that wants to assign, discharge, or amend its own interests under the Cape Town Convention, which the UAE has ratified. ${ }^{123}$ The authorization code is used to enter these interests into the International Registry, but the entity must provide its information to the GCAA's Aircraft Registry, because that is the authorizing entry point for the UAE. ${ }^{124}$

As discussed previously, while the UAE has made a declaration regarding Protocol Article VIII, stating that contracting parties may choose which country's laws will govern their contractual rights and obligations, it is still uncertain how this will come into play in actual practice. Right now it is unknown if the UAE would respect another country's decisions on a contractual rights or obligations issue. One way to attempt to overcome this uncertainty is to include in the contract that rather than going to court, any issue regarding the contractual rights or obligations will instead go to arbitration or be submitted to the courts of the Dubai International Financial Centre (DIFC). ${ }^{125}$ In regards to arbitration, the UAE is a party to the New York Convention on Recognition of Foreign Arbitral Awards 1958, meaning that the UAE should recognize and allow enforcement upon most arbitral decisions made by another contracting state, although there are a few exceptions. ${ }^{126}$ While in theory this would work, in practice only some courts have agreed to enforce other contracting state's arbitral decisions. ${ }^{127}$ Another alternative, which might be the best solution, is the submission of the issue to the DIFC. Dubai Law No. 16 of 2011 proclaims that the DIFC has jurisdiction to hear a claim that is submitted to them. ${ }^{128}$ According to attorney Emma Giddings, "[t]he DIFC is a self standing common law jurisdiction within the Emirate of Dubai and its courts would respect the choice of a foreign law to govern contracts." 129 While this seems like the perfect solution, Law No. 16 has not been significantly tested and it cannot be certain if this will work as a contracting party would hope. ${ }^{130}$

The actual leases and financing agreements over aircraft in the UAE are more complicated than traditional aviation financing and leasing practices due to the Sharia. UAE's laws, mainly UAE Federal Law No. 5 of 1985 of the Civil Code,

${ }^{121} I d$.

${ }^{122} I d$.

123 Authorizing Entry Point-Cape Town Convention, U.A.E. Gen. Civ. AviATion Auth., https://www.gcaa.gov.ae/en/Departments/AS/Pages/aep.aspx (last visited May 1, 2015).

${ }^{124} I d$.

${ }^{125}$ Giddings, supra note 58.

${ }^{126} \mathrm{Id}$.

${ }^{127} \mathrm{Id}$.

${ }^{128} \mathrm{Id}$.

${ }^{129} I d$.

${ }^{130} \mathrm{Id}$. 
recognize a lease as a contractual right to use the aircraft, but the lease itself does not grant any proprietary rights of the aircraft. ${ }^{131}$ While the Sharia does not allow surety, the way to get around this issue, under the UAE's Commercial Code, is by making sure the mortgagee has possession of the aircraft. ${ }^{132}$ UAE Federal Law No. 18 of 1993 of the Commercial Code sets out the following requirements in order for the mortgagee to be considered in possession of aircraft: "the installation of name plates on the aircraft and engines, the fact that the aircraft registration will include details of the mortgagee's interest[,] and . . . the fact that the mortgage will usually be registered as an international interest under the Cape Town Convention." ${ }^{\prime 33}$ Due to these requirements, it is not uncommon for the mortgage to be taken in another country if the aircraft can be in the other country at that time. ${ }^{134}$

The UAE's Civil Code also addresses the Islamic financing principle of sharing risks between all parties, which is very different than traditional financing and leasing methods. The Civil Code creates the presumption that "the lessor will be responsible primarily for ensuring the continued enjoyment of the leased asset by the lessee and that the lessee will cease to be liable under the lease to the extent that its enjoyment of the leased asset is interrupted." ${ }^{135}$ There is a chance that this Sharia principle may be overcome, because the UAE law gives weight to freedom of contract, which may allow the parties to contract the terms differently. ${ }^{136}$

Article 54(2) of the Cape Town Convention declares that:

[a] Contracting State shall, at any time of ratification, acceptance, approval of, or accession to the Protocol, declare whether or not any remedy available to the creditor under any provision of this Convention which is not there expressed to require application to the court may be exercised only with leave of the court. ${ }^{137}$

The UAE has decided, according to this article, that any remedies under the Cape Town Convention regarding repossession and deregistration that do not require court approval may only be allowed through a motion for leave of court. ${ }^{138}$ The UAE has a process where court approval is not explicitly required called Irrevocable DeRegistration and Export Request Authorization (IDERA). ${ }^{139}$ While the GCAA was the agency that created IDERA, they are unlikely to pursue any action through it
${ }^{131} I d$.
${ }^{132} I d$.
${ }^{133} \mathrm{Id}$.
${ }^{134} \mathrm{Id}$.
${ }^{135} \mathrm{Id}$.
${ }^{136} \mathrm{Id}$.
${ }^{137}$ Cape Town Convention, supra note 60, at 134.
${ }^{138}$ Giddings, supra note 58.

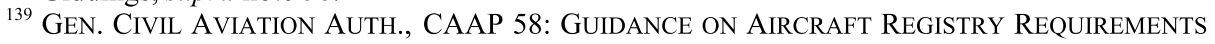
(2012), https://www.gcaa.gov.ae/en/epublication/admin/Publication $\% 20$ History/Civil\%20Aviation $\% 20$ Advisory\%20Publication\%20(CAAP)/CAAP\%2058\%20GUIDANCE\%20ON\%20AIRCRAFT\%20RE GISTRATION\%20REQUIREMENTS.pdf, construed in Giddings, supra note 58. 
without a court order. ${ }^{140}$ While not yet tested in the UAE, the country did agree to Protocol Article $\mathrm{X}^{141}$ to allow for parties to get quick relief with a contractual rights or obligations issue; so, there is hope that this will help with the repossession and deregistration process in the future. ${ }^{142}$ This shows the unlikeliness of getting around a court order for repossession and deregistration within the UAE.

Under Protocol Article XI, a State has two choices of declarations it can make as to the procedure it may take when the insolvency of a lessee becomes an issue: Alternative A or Alternative B. ${ }^{143}$ The country does not have to make a declaration

${ }^{140}$ Giddings, supra note 58.

${ }^{141}$ Article X-Modification of Provisions Regarding Relief Pending Final Determination: 1. This Article applies only where a Contracting State has made a declaration under Article $\mathrm{XXX}(2)$ and to the extent stated in such declaration.

2. For the purposes of Article 13(1) of the Convention, "speedy" in the context of obtaining relief means within such number of working days from the date of filing of the application for relief as is specified in a declaration made by the Contracting State in which the application is made.

3. Article 13(1) of the Convention applies with the following being added immediately after sub-paragraph (d): '(e) if at any time the debtor and the creditor specifically agree, sale and application of proceeds therefrom', and Article 43(2) applies with the insertion after the words 'Article 13(1)(d)' of the words 'and (e).' 4. Ownership or any other interest of the debtor passing on a sale under the preceding paragraph is free from any other interest over which the creditor's international interest has priority under the provisions of Article 29 of the Convention.

5. The creditor and the debtor or any other interested person may agree in writing to exclude the application of Article 13(2) of the Convention.

6. With regard to the remedies in Article IX(1):

(a) they shall be made available by the registry authority and other administrative authorities as applicable, in a Contracting State no later than five working days after the creditor notifies such authorities that the relief specified in Article IX(1) is granted or, in the case of relief granted by a foreign court, recognized by a court of that Contracting State, and that the creditor is entitled to procure those remedies in accordance with the Convention; and

(b) the applicable authorities shall expeditiously co-operate with and assist the creditor in the exercise of such remedies in conformity with the applicable aviation safety laws and regulations."

7. Paragraphs 2 and 6 shall not affect any applicable aviation safety laws and regulations.

Cape Town Protocol, supra note 36, at art. X.

${ }^{142}$ Giddings, supra note 58.

${ }^{143}$ Article XI-Remedies on Insolvency:

1. This Article applies only where a Contracting State that is the primary insolvency jurisdiction has made a declaration pursuant to Article $\mathrm{XXX}(3)$.

Alternative A.

2. Upon the occurrence of an insolvency-related even, the insolvency administrator or the debtor, as applicable, shall, subject to paragraph 7, give possession of the aircraft object to the creditor no later than the earlier of:

(a) the end of the waiting period; and

(b) the date on which the creditor would be entitled to possession of the aircraft object if this Article did not apply.

3. For the purposes of this Article, the "waiting period" shall be the period specified in a declaration of the Contracting State which is the primary insolvency 
jurisdiction.

4. References in this Article to the "insolvency administrator" shall be to that person in its official, not in its personal, capacity.

5. Unless and until the creditor is given the opportunity to take possession

under paragraph 2 :

(a) the insolvency administrator or the debtor, as applicable, shall preserve the aircraft object and maintain it and its value in accordance with the agreement; and

(b) the creditor shall be entitled to apply for any other forms of interim relief available under the applicable law.

6. Sub-paragraph (a) of the preceding paragraph shall not preclude the use of the aircraft object under arrangements designed to preserve the aircraft object and maintain it and its value.

7. The insolvency administrator or the debtor, as applicable, may retain possession of the aircraft object where, by the time specified in paragraph 2, it has cured all defaults other than a default constituted by the opening of insolvency proceedings and has agreed to perform all future obligations under the agreement. A second waiting period shall not apply in respect of a default in the performance of such future obligations.

8. With regard to the remedies in Article IX(1):

(a) they shall be made available by the registry authority and the administrative authorities in a Contracting State, as applicable, no later than five working days after the date on which the creditor notifies such authorities that it is entitled to procure those remedies in accordance with the Convention; and

(b) the applicable authorities shall expeditiously co-operate withand assist the creditor in the exercise of such remedies in conformity with the applicable aviation safety laws and regulations.

9. No exercise of remedies permitted by the Convention or this Protocol may be prevented or delayed after the date specified in paragraph 2 .

10 . No obligations of the debtor under the agreement may be modified without the consent of the creditor.

11. Nothing in the preceding paragraph shall be construed to affect the authority, if any, of the insolvency administrator under the applicable law to terminate the agreement.

12. No rights or interests, except for non-consensual rights or interests of a category covered by a declaration pursuant to Article 39(1), shall have priority in insolvency proceedings over registered interests.

13. The Convention as modified by Article IX of this Protocol shall apply to the exercise of any remedies under this Article.

Alternative $B$

2. Upon the occurrence of an insolvency-related event, the insolvency administrator or the debtor, as applicable, upon the request of the creditor, shall give notice to the creditor within the time specified in a declaration of a Contracting State pursuant to Article XXX(3) whether it will:

(a) cure all defaults other than a default constituted by the opening

of insolvency proceedings and agree to perform all future obligations, under

the agreement, and related transaction documents; or

(b) give the creditor the opportunity to take possession of the aircraft object, in accordance with the applicable law.

3. The applicable law referred to in sub-paragraph (b) of the preceding paragraph may permit the court to require the taking of any additional step or the provision of any additional guarantee.

4. The creditor shall provide evidence of its claims and proof that its international interest has been registered.

5. If the insolvency administrator or the debtor, as applicable, does not give notice 
at all, and instead may follow its own insolvency laws. ${ }^{144}$ All six of the Middle Eastern countries that ratified the Protocol and made a declaration as to Article XI chose Alternative A with a time period of sixty days, meaning the insolvency administrator has sixty calendar days to pay all of the defaults and must consent to execute all future obligations. ${ }^{145}$ If the insolvency administrator fails to take these required actions, the administrator must allow the creditor to take possession of the aircraft. ${ }^{146}$ A specific point under this alternative is that the court cannot intervene and is not allowed to help with the reorganization of an insolvent lessee. ${ }^{147}$ Under Alternative B, if the insolvent administrator fails to pay the defaults and does not consent to performing the future obligations, the court may order the terms in which the creditor can take possession of the aircraft. ${ }^{148}$ Even though the UAE made a declaration to apply Alternative A with a sixty-day period, it is unclear how this would actually be applied, especially as to the time constraints set out by the State. ${ }^{149}$ The insolvency process within this country is very rarely used and is extremely time consuming, which is in part due to the Sharia. ${ }^{150}$ Due to the complexities that can arise through the Sharia being applied by the courts to matters of insolvency, it is more likely for companies governed by UAE laws to develop restructuring plans with their creditor rather than to use the legal insolvency process. ${ }^{151}$

One final aspect of financing and leasing aircraft within the UAE is that one must pay particular attention to sovereign immunity. ${ }^{152}$ Some of the UAE's airlines have sovereign immunity under the UAE's federal laws and the laws of each individual Emirate. This should be considered before transactions with these airlines are conducted. ${ }^{153}$

As established by this Case Study, aviation financing and leasing transactions in Middle Eastern nations that follow Sharia law can become complex and risky. However, this risk can be partially offset by the risk sharing required under Islamic

in conformity with paragraph 2 , or when the insolvency administrator or the debtor has declared that it will give the creditor the opportunity to take possession of the aircraft object but fails to do so, the court may permit the creditor to take possession of the aircraft object upon such terms as the court may order and may require the taking of any additional step or the provision of any additional guarantee.

6 . The aircraft object shall not be sold pending a decision by a court regarding the claim and the international interest.

Cape Town Protocol, supra note 36, at art. XI; see also Goode, supra note 58.

${ }^{144}$ Goode, supra note 58.

${ }^{145}$ See Cape Town Convention on International Interests in Mobile Equipment and its Aircraft Protocol-Summary of National Implementation, supra note 62; see also app. C; Goode, supra note 57.

${ }^{146}$ Goode, supra note 58.

${ }^{147} \mathrm{Id}$.

${ }^{148} I d$.

${ }^{149}$ Giddings, supra note 58.

${ }^{150} \mathrm{Id}$.

${ }^{151} \mathrm{Id}$.

${ }^{152}$ Id.

${ }^{153} \mathrm{Id}$. 
aviation financing.

\section{CONCLUSION}

Overall, Islamic finance is likely to continue to grow and should be considered by companies interested in aviation financing and leasing. One great example of recent Islamic aviation financing growth is the joint venture that Palma Holding and Ibdar Bank are working together on as a way to break into the aviation leasing field. ${ }^{154}$ Most recently, they procured three more BombardierQ400 NextGen aircraft that will be leased to Falcon Aviation Services in Abu Dhabi. ${ }^{155}$ This transaction was the third "Shari'ah compliant leasing transaction" done by the joint venture. ${ }^{156}$ The CEO of Ibdar Bank, Basel Al-Hag-Issa's comments on the transaction were: "This lease agreement . . continues to show our commitment to originating and structuring innovative Shari'ah compliant financing opportunities for investors, who are seeking exposure to strong, asset backed products that provide attractive yields." 157

Another recent example of Islamic financing growth across the globe is Emirates' recent transaction concerning US\$913,026,000 Certificates, discussed in the Introduction. ${ }^{158}$ This transaction is "the world's first Sukuk financing supported by [UK Export Finance] and the largest ever capital markets offering in the aviation space with an Export Credit Agency." 159 One unique aspect of this deal was the fact that it attracted both traditional and Islamic investors worldwide. ${ }^{160}$

${ }^{154}$ Palma and Ibdar Venture Bring Three More Q400s for Falcon Aviation, ARABIAN AEROSPACE ONLINE NEWS SERV. (Apr. 29, 2015), http://www.arabianaerospace.aero/palma-and-ibdar-venture-bringthree-more-q400s-for-falcon-aviation.html.

${ }^{155} \mathrm{Id}$.

${ }^{156} \mathrm{Id}$.

${ }^{157} \mathrm{Id}$.

${ }^{158}$ Emirates Set to Close US\$913 Million Sukuk, ArabIAn AEROSPACE OnLINE NewS SERV. (Mar. 30, 2015), http://www.arabianaerospace.aero/emirates-set-to-close-us-913-million-sukuk.html.

${ }^{159} \mathrm{Id}$. 
APPENDIX A

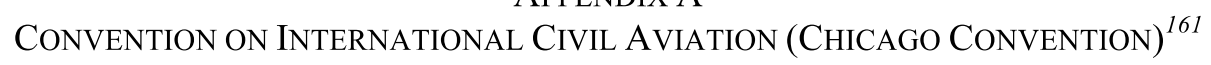

\begin{tabular}{|c|c|c|}
\hline Country & $\begin{array}{c}\text { Ratification or Notice of } \\
\text { Adherence } \\
\end{array}$ & Date \\
\hline Afghanistan & Ratified & April 4, 1947 \\
\hline Bahrain & Notice of Adherence & August 20, 1971 \\
\hline Egypt & Ratified & March 13, 1947 \\
\hline Islamic Republic of Iran & Ratified & April 19, 1950 \\
\hline Iraq & Ratified & June 2, 1947 \\
\hline Israel & Notice of Adherence & May 24, 1949 \\
\hline Jordan & Notice of Adherence & March 18, 1947 \\
\hline Kuwait & Notice of Adherence & May 18,1960 \\
\hline Lebanon & Ratified & September 19,1949 \\
\hline Oman & Notice of Adherence & January 24, 1973 \\
\hline Pakistan & Notice of Adherence & November 6, 1947 \\
\hline Qatar & Notice of Adherence & September 5, 1971 \\
\hline $\begin{array}{l}\text { Kingdom of } \\
\text { Saudi Arabia } \\
\end{array}$ & Notice of Adherence & February 19,1962 \\
\hline Syrian Arabia Republic & Ratified & December 21, 1949 \\
\hline Turkey & Ratified & December 20, 1945 \\
\hline United Arab Emirates & Notice of Adherence & April 25, 1972 \\
\hline Yemen & Notice of Adherence & April 17, 1964 \\
\hline
\end{tabular}

${ }^{161}$ Convention on International Civil Aviation Signed at Chicago on 7 December 1944, supra note 43. 
APPENDIX B

CONVENTION ON THE INTERNATIONAL RECOGNITION OF RIGHTS IN AIRCRAFT (GENEVA CONVENTION) $^{162}$

\begin{tabular}{|c|c|}
\hline Country & $\begin{array}{c}\text { Deposited Instrument of Ratification, } \\
\text { Adherence, or Succession? } \\
\text { If yes, date. } \\
\end{array}$ \\
\hline Afghanistan & No \\
\hline Bahrain & Yes - March 3, 1997 \\
\hline Egypt & Yes - September 10, 1969 \\
\hline Islamic Republic of Iran & $\begin{array}{c}\text { No, but it did sign the treaty - March } 18, \\
1950\end{array}$ \\
\hline Iraq & Yes - January 12, 1981 \\
\hline Israel & No \\
\hline Jordan & No \\
\hline Kuwait & Yes - November 27, 1979 \\
\hline Lebanon & Yes - April 11, 1969 \\
\hline Oman & Yes - March 19, 1992 \\
\hline Pakistan & Yes - June 19, 1953 \\
\hline Qatar & Yes - April 20, 2007 \\
\hline Saudi Arabia & No \\
\hline Syrian Arab Republic & No \\
\hline Turkey & No \\
\hline United Arab Emirates & No \\
\hline Yemen & No \\
\hline
\end{tabular}

${ }^{162}$ Convention on the International Recognition of Rights in Aircraft Signed at Geneva on 19 June 1948, supra note 49. 
APPENDIX C

CAPE TOWN CONVENTION AND PROTOCOL ${ }^{163}$

\begin{tabular}{|c|c|c|c|c|}
\hline \multirow[b]{2}{*}{ Countries } & $\begin{array}{c}\text { Convention on } \\
\text { International } \\
\text { Interests in } \\
\text { Mobile } \\
\text { Equipment }\end{array}$ & $\begin{array}{c}\text { Protocol to the } \\
\text { Convention on } \\
\text { International } \\
\text { Interests in } \\
\text { Mobile } \\
\text { Equipment on } \\
\text { Matters } \\
\text { Specific to } \\
\text { Aircraft } \\
\text { Equipment }\end{array}$ & & \\
\hline & $\begin{array}{c}\text { Ratified? } \\
\text { If yes, date. }\end{array}$ & $\begin{array}{c}\text { Ratified? } \\
\text { If yes, date. }\end{array}$ & $\begin{array}{l}\text { Did the } \\
\text { country make } \\
\text { a Qualifying } \\
\text { Declaration } \\
\text { regarding } \\
\text { Protocol } \\
\text { Article VIII? }\end{array}$ & $\begin{array}{c}\text { Did the } \\
\text { country make } \\
\text { a Qualifying } \\
\text { Declaration } \\
\text { regarding } \\
\text { Protocol } \\
\text { Article XI? } \\
\text { If yes, which } \\
\text { Alternative } \\
\text { was chosen } \\
\text { and what was } \\
\text { the specified } \\
\text { time period? }\end{array}$ \\
\hline Afghanistan & $\begin{array}{c}\text { Yes - } \\
\text { July 25, } 2006\end{array}$ & $\begin{array}{c}\text { Yes }- \\
\text { July 25, } 2006\end{array}$ & Yes & $\begin{array}{c}\text { Yes }- \\
\text { Alternative A, } \\
60 \text { days }\end{array}$ \\
\hline Bahrain & $\begin{array}{c}\text { Yes - } \\
\text { November 27, } \\
2012\end{array}$ & $\begin{array}{c}\text { Yes }- \\
\text { November 27, } \\
2012\end{array}$ & No & No \\
\hline Egypt & $\begin{array}{c}\text { Yes - } \\
\text { December 10, } \\
2014\end{array}$ & $\begin{array}{c}\text { Yes }- \\
\text { December 10, } \\
2014\end{array}$ & $\begin{array}{l}\text { Not yet } \\
\text { specified }\end{array}$ & $\begin{array}{l}\text { Not yet } \\
\text { specified }\end{array}$ \\
\hline Iraq & No & No & Not Applicable & Not Applicable \\
\hline
\end{tabular}

${ }^{163}$ Convention on International Interests in Mobile Equipment (Cape Town 2001)—Status, supra note 52; Protocol on the Convention on International Interests in Mobile Equipment on Matters Specific to Aircraft Equipment-Status, supra note 53.

164 Cape Town Convention on International Interests in Mobile Equipment and its Aircraft Protocol-Summary of National Implementation, supra note 63.

${ }^{165} \mathrm{Id}$. 


\begin{tabular}{|c|c|c|c|c|}
\hline $\begin{array}{c}\text { Islamic } \\
\text { Republic of Iran }\end{array}$ & No & No & Not Applicable & Not Applicable \\
\hline Israel & No & No & Not Applicable & Not Applicable \\
\hline Jordan & $\begin{array}{c}\text { Yes - August } \\
31,2013\end{array}$ & $\begin{array}{c}\text { Yes - August } \\
31,2013\end{array}$ & Yes & $\begin{array}{c}\text { Yes - } \\
\text { Alternative A, } \\
60 \text { days }\end{array}$ \\
\hline Kuwait & $\begin{array}{c}\text { Yes - October } \\
30,2013 \\
\end{array}$ & $\begin{array}{c}\text { Yes - October } \\
31,2013 \\
\end{array}$ & No & No \\
\hline Lebanon & No & No & Not Applicable & Not Applicable \\
\hline Oman & $\begin{array}{c}\text { Yes - March } \\
21,2005\end{array}$ & $\begin{array}{c}\text { Yes - March } \\
21,2005\end{array}$ & Yes & $\begin{array}{c}\text { Yes - } \\
\text { Alternative A, } \\
60 \text { days }\end{array}$ \\
\hline Pakistan & $\begin{array}{c}\text { Yes - January } \\
22,2004\end{array}$ & $\begin{array}{c}\text { Yes - January } \\
22,2004\end{array}$ & Yes & $\begin{array}{c}\text { Yes - } \\
\text { Alternative A, } \\
60 \text { days }\end{array}$ \\
\hline Qatar & No & No & Not Applicable & Not Applicable \\
\hline $\begin{array}{l}\text { Kingdom of } \\
\text { Saudi Arabia }\end{array}$ & $\begin{array}{c}\text { Yes- June 27, } \\
2008\end{array}$ & June 27, 2008 & No & No \\
\hline $\begin{array}{c}\text { Syrian Arab } \\
\text { Republic }\end{array}$ & $\begin{array}{c}\text { Yes }- \text { August } 7, \\
2007\end{array}$ & No & Not Applicable & Not Applicable \\
\hline Turkey & $\begin{array}{c}\text { Yes - August } \\
23,2011\end{array}$ & $\begin{array}{c}\text { Yes - August } \\
23,2011\end{array}$ & Yes & $\begin{array}{c}\text { Yes - } \\
\text { Alternative A, } \\
60 \text { days }\end{array}$ \\
\hline $\begin{array}{c}\text { United Arab } \\
\text { Emirates }\end{array}$ & $\begin{array}{c}\text { Yes - April 29, } \\
2008\end{array}$ & $\begin{array}{c}\text { Yes - April 29, } \\
2008\end{array}$ & Yes & $\begin{array}{c}\text { Yes - } \\
\text { Alternative A, } \\
60 \text { days }\end{array}$ \\
\hline Yemen & No & No & Not Applicable & Not Applicable \\
\hline
\end{tabular}


